\title{
Prior Knowledge in EFL Reading Comprehension: Omani Teachers' Perspectives \& Classroom Strategies
}

\author{
Yahya Al-Jahwari \\ Ministry of Education, Oman \\ E-mail: arabiom@hotmail.com \\ Salma Al-Humaidi \\ Sultan Qaboos University, Oman \\ E-mail: shumaidi@squ.edu.om
}

Received: 05-07-2014

doi:10.7575/aiac.ijalel.v.4n.1p.169
Accepted: 05-09-2014

Published: 01-01-2015

URL: http://dx.doi.org/10.7575/aiac.ijalel.v.4n.1p.169

\begin{abstract}
The study investigated three main aspects related to prior knowledge in EFL reading comprehension in Oman: teachers' view of the role of prior knowledge, the instructional strategies they use for activating students' prior knowledge, and the difficulties they face when activating students' prior knowledge. To this end, three instruments were used: a questionnaire, an observation checklist, and a semi-structured interview. The findings of the study showed a strong agreement of the role of prior knowledge in text comprehension, a heavy reliance on a limited number of techniques and a clear attribution of the difficulties to sources such as students' limited linguistic competence and lack of adequate teacher training on schema theory and its instructional techniques. In light of the findings, some implications for EFL teachers, in-service teachers training, and for curriculum development are given.
\end{abstract}

Keywords: prior knowledge, schema, classroom strategies, reading comprehension

\section{Introduction}

\subsection{Statement of the Problem}

Schema theory has had a major influence on reading comprehension, which is viewed as an interactive process that requires the simultaneous performance of various mental operations. Berhnardt (1991) and Brantmeier (2004) pointed out that the activation of prior knowledge or schema is one of these operations. Studies on the role of prior knowledge (e.g. Murray, 1980 and Anderson, 1994) have shown that it has great impact on reading comprehension in a foreign language. These studies have made it clear that understanding the role of schema in the reading process provides deep insights into why students may fail or succeed in comprehending the written text.

In Oman, there is a lack of empirical studies on how teachers understand and implement schema theory in teaching reading. In fact, reading has been investigated from numerous perspectives and several problems were identified by these studies. For instance, Al Ajmi (2006) found that the first reading difficulty encountered by Omani students relates to 'content/world background knowledge'. In her view, these could be attributed to the type of reading texts or teachers' instructional strategies. Another study conducted by Al Brashdi (2002) also found that 'background knowledge' is among the three most serious problems facing Omani students when constructing meaning from written texts. Both studies focused only on teachers' and students' perspectives on the reading difficulties encountered by Omani students, but did not examine English teachers' instructional practices.

Despite the large number of studies on the effects of prior knowledge on students' reading comprehension (Johnson, 1981; Carrell and Eisterhold, 1983; \&Barnet, 1989), there is lack of studies on how teachers understand the role of prior knowledge in EFL reading comprehension and what strategies they apply in the classroom to deal with it. August and Hakuta (1997) as cited in Chen (2003) pointed out that more research is needed to understand how to optimize reading comprehension instruction especially in EFL contexts.

In Oman, to the researchers' best knowledge there is an absence of studies that dealt with this issue. The two studies conducted by Al Ajmi (2006) and Al Brashdi (2002) focused only on addressing the reading difficulties encountered by Omani students from teachers' and students' perspectives, but they did not examine teachers' instructional practices. Although reading has become the main concern of the Ministry of Education recently through different attempts to identify the obstacles, still teachers' practices in teaching reading are not clear yet. As a result, there is a need for a systematic investigation of teachers' understanding of the role of prior knowledge in reading comprehension and the instructional techniques that they use to enhance EFL students' reading comprehension. 


\subsection{Purpose of the Study}

This study sought to investigate three main aspects related to prior knowledge in EFL reading comprehension: the teachers' view of the role of prior knowledge, the instructional strategies they use to activate students' prior knowledge, and the difficulties they face when activating prior knowledge in teaching reading.

\subsection{Questions of the Study}

In order to achieve its purpose, the study attempted to answer the following questions:

a. How do Omani EFL teachers view the role of prior knowledge in reading comprehension?

b. What are the instructional strategies the teachers use to foster the activation of prior knowledge in the Omani EFL classroom?

c. What are the difficulties that Omani EFL teachers face when activating prior knowledge in the Omani EFL classroom?

\section{Related Literature}

\subsection{Schema Theory and Reading Comprehension}

The understanding of the role of schema in the reading process provides insights into why students may fail or succeed in comprehending text content. For instance, Murray (1980) pointed out that schema influences comprehension in several ways. It influences information recall as well as information storage. It shuts out irrelevant information and alters recall after reading.

Anderson (1994) also believes that in reading comprehension the schemata enable readers to make inferences and fill in information not embedded explicitly in the text. The readers use text clues and the knowledge stored in their schema to infer implicit information.

\subsection{Functions and Types of Schemata}

In order to understand the role of schema in reading comprehension, Carrell and Eisterhold (1983), and Alderson (2000) made a clear distinction between two major types of schemata, formal schemata and content schemata, which are both closely related to the success of reading comprehension. According to Carrell and Eisterhold (1983), formal schema refers to the organizational forms and rhetorical structures of texts. The content schema refers to the background knowledge of the content area of the text. In other words, it refers to a reader's prior knowledge on a given topic.

\subsection{Content schema and Reading Comprehension}

Several studies (Johnson, 1981; Carrell and Eisterhold, 1983; Lipson, 1983, cited in Dayze, 2004; and Al-Issa, 2006) found that content schemata affect comprehension more than formal schemata. Readers can comprehend better when the content is familiar to them. In other words, the more the reader knows about the topic, the more easily he understands the information of the text.

The influences of a reader's schemata on reading comprehension are further supported by studies showing that comprehension of culturally-familiar materials is easier than that of culturally- unfamiliar materials. For instance, Lipson's study (1983), cited in Dayze (2004) indicates that reading a culturally-familiar passage had a strong effect on participants' post reading performance. The study showed that readers read the culturally-familiar text faster, recalled more text-based and implicit propositions, and also made fewer mistakes on their recall of the passage. Also, Johnson (1981) investigated the effect of the cultural origin of prose on the reading comprehension of Iranian intermediate and advanced learners of English (ESL) at the university level. The results revealed that the cultural origin of the stories had a greater effect on comprehension than the syntactic or semantic complexity of the text.

Therefore, according to schema theory, EFL reading classes should utilize pre-reading activities to activate prior knowledge and teachers should provide the needed prior knowledge for students, especially due to cultural differences. Similarly, Chen (2003) points out that the teachers need to be aware of what prior knowledge and experiences students bring to the reading task. Then, teachers can activate the prior knowledge before reading a text through appropriate prereading activities such as setting purpose for reading, building text-specific knowledge, pre-teaching of key vocabulary, and making predictions.

\subsection{Schema Activation \& Teachers' Role}

Abraham (2002) states that teaching reading "demands that the teachers activate the students' schema during the prereading phase by helping students recognize the knowledge that they already have about the topic of a text" (p. 6). Also, Carrell and Floyd (1987) argue that teachers must provide their students with the appropriate schemata they lack, and must also help them to build bridges between existing knowledge and new knowledge. Similarly, Al-Issa (2006) indicates that reading teachers must take into account that prior knowledge is required by any written text. Therefore, reading teachers should help readers to activate their prior knowledge through problem solving, creative, interpretive strategies in which the students can use whatever knowledge or resources they may have. In teaching students to activate and use their prior knowledge, teachers are helping them to become good readers.

\subsection{Pre-Reading to Activate Prior Knowledge}

Pre-reading activities play a crucial role in schema theory. Based on schema theory view, reading requires schema activation before starting to read in order to comprehend the text better (Carrell and Eisterhold 1983; Grabe 1991; \& Ur 
1996). Ringler and Weber (1984) define pre-reading activities as enabling activities, because they provide readers with the necessary prior knowledge to comprehend the content. They argue that pre-reading activities elicit prior knowledge, build prior knowledge, and focus students' attention. Similarly, Spires and Donley (1998) emphasized that the prereading activities help students to make connections between their existing knowledge and new information that they will find in the reading text.

For the purposes of the present study, the ten main strategies in the literature that will be adopted later for the classroom observation will be discussed. These strategies are: brainstorming, classroom discussion, semantic mapping, graphic organizers, anticipation guide, audiovisual aids, questioning, prediction, linking topic to students' culture, and KWL.

\section{Methodology}

\subsection{Population and Sample}

The study was conducted with sixth and seventh Grades Basic Education teachers in Batinah North Region for the Academic Year 2009-2010. The population consisted of 217 EFL Omani teachers, 129 females and 88 males. The sample for the questionnaire of the study consisted of 82 teachers. The sample for the observation consisted of 30 teachers.

\subsection{Research Instruments \& Procedures}

Three instruments were used for the purpose of the present study: a questionnaire, an observation checklist and a semistructured interview.

The validity of the design of the instruments used in the present study was established by consulting a jury composed of sixteen experts who checked the clarity and relevance of each item. The jury was composed of faculty members from the College of Education, College of Arts at Sultan Qaboos University, and some experts in the Ministry of Education.

The reliability of the questionnaire was determined through a piloting sample with twenty teachers selected randomly for this purpose. The reliability coefficient of the questionnaire was found to be 0.76 .

The inter-reliability of the observation checklist of the current study was established by checking the performance of five teachers by two different observers, the researcher and a regional supervisor. Then, the reliability coefficient for the observation checklist was computed by calculating the percentage of agreement between the two observers which was found to be $90 \%$.

\subsection{Data Collection}

The researcher observed thirty reading lessons with thirty teachers. Then, the researcher distributed the questionnaires to Cycle Two schools in Batinah North with a prior arrangement by the Senior English Supervisor; only 82 questionnaires were returned, which represent about $40 \%$ of the population.

\section{Results and Discussion: Answering the Research Questions}

\subsection{Teachers' view of the role of prior knowledge in reading comprehension}

In order to investigate teachers' views, the questionnaire focused on four aspects related to the role of prior knowledge in students' comprehension: the role of prior knowledge about the text topic, teachers' views of a good reader, teachers' role in fostering text comprehension through the use of students' prior knowledge, and teachers' instructional practices to activate students' prior knowledge. The grand means and standard deviations of teachers' perceptions of the role of prior knowledge in reading comprehension were calculated and summarized in Table 1.

Table 1. The overall Means and Standard deviation of Teachers' views of the role of the prior knowledge

$\mathrm{N}$ Aspects related to the role of prior knowledge

1 Teachers' views of the role of the prior knowledge of a text topic

2 Teachers' views of good readers

3 Teachers' views of the role of the teacher

4 Teachers' views of their reading instructional practices
Mean

4.10

4.07
$\mathrm{SD}$

.66

.88

As Table (1) shows, EFL teachers' answers generally indicate a strong agreement on the role of prior knowledge in reading comprehension. The highest mean score was obtained by the third aspect "teachers' views of the role of the teacher" with a mean score of (4.39). Therefore, these results show that the four aspects related to the role of prior knowledge were recognized by Omani EFL teachers as rather important. The following tables show more precisely the data related to teachers' perceptions. 
Table 2. Means and Standard deviation of Teachers' views of the role of the prior knowledge of a text topic

\begin{tabular}{llll}
$\mathrm{N}$ & $\begin{array}{l}\text { When students have sufficient prior knowledge about text topic, they } \\
\text { can: }\end{array}$ & Mean & SD \\
\cline { 2 - 4 } 1 & Understand text better & 4.57 & .62 \\
2 & Recall information easily & 4.39 & .66 \\
3 & Read text quickly & 3.85 & .98 \\
4 & Link the ideas in the text easily & 4.13 & .81 \\
5 & Focus on main ideas & 3.98 & .93 \\
6 & Overcome limited linguistic knowledge & 3.57 & 1.06 \\
7 & Relate text to their own prior knowledge & 4.25 & 1.08 \\
8 & Predict text content easily & 4.12 & .72 \\
9 & Confirm predictions based on prior knowledge & 4.06 & .79 \\
\hline
\end{tabular}

As Table (2) shows, EFL teachers' answers indicate a strong agreement on the role of prior knowledge of text topic. Most means were above (4.0), which indicates high positive responses. For example, the mean score for the first item "Understand text better" was (4.57), and the mean score for the second item "Recall information easily" was (4.39).

However, Omani EFL teachers' perception regarding the role of prior knowledge about text topic decreased for items number six "Overcome limited linguistic knowledge" with a mean score of (3.57), and item number three "Read text quickly" with a mean score of (3.85).

It seems that Omani EFL teachers are aware of the role of sufficient prior knowledge about text topic in reading comprehension. Interestingly, although both scores are high, EFL teachers assign a much bigger role to prior knowledge in recall and comprehension than its role in helping students to overcome the limited linguistic knowledge and to read texts quickly. This finding is supported by previous studies such as and Nicolich, (1980). They found that sufficient prior knowledge can enhance passage recall.

Table 3. Means and Standard deviation of Teachers' views of good readers

\begin{tabular}{llll}
$\mathrm{N}$ & The Good readers: & Mean & SD \\
\cline { 2 - 4 } 10 & use their personal knowledge of the topic of the text to make sense of the text & 4.37 & .65 \\
11 & are able to activate their prior knowledge to create meaning of the text & 4.30 & .67 \\
12 & use text title, illustrations and other clues to predict the content & 4.47 & .72 \\
13 & use the directions provided by the text to construct meaning & 4.07 & .88 \\
\hline
\end{tabular}

The results shown in Table (3) also indicate a strong agreement on the four characteristics of good readers. The highest mean score was obtained by item number 12 that good readers "Use text's title, illustrations and other clues to predict the content" with a mean score of (4.47). Also, item number 10 "Use their personal knowledge of the topic to make sense of the text" obtained a mean score of (4.37) of teachers' responses. "Good readers' ability to activate their prior knowledge to create meaning" came third with a mean of (4.30).

From the above results, we can conclude that Omani EFL teachers give a great importance to the role of prior knowledge as a main criterion of good readers. They view readers as active rather than passive. From teachers' point of view, the good reader should use the content to create the meaning.

Table 4. Means and Standard deviation of Teachers' views of the role of the teacher

$\mathbf{N}$

To foster text comprehension with the use of students' prior knowledge, it is important for teachers to:

14

15

Activate available prior knowledge

16 Identify the absence of knowledge

17 Raise students' awareness of the role of prior knowledge

18 Ask questions before, during and after reading

19 Encourage students to summarize what they have read

20 Elicit background information related to the reading topic
Mean SD

$4.47 \quad .59$

4.53

4.04

4.24

4.64

4.40

4.45

.61 
The results in Table (4) reveal a strong agreement on the teacher's role in fostering text comprehension through the use of students' prior knowledge. The highest mean score was obtained by item number 18 "Ask questions before, during, and after reading" with a mean score of (4.64). Also, item number 15 "Activate available prior knowledge" and item number 14 "Provide students with appropriate prior knowledge" obtained means of (4.53) and (4.47) respectively.

The possible explanation for these results is that the teachers are aware of the importance of fostering text comprehension through the use of students' prior knowledge. Another possible explanation may be that teachers think that the techniques proposed in Table (4) lead to automatic text comprehension without any attention to the types of these techniques. This possibility is supported by teachers' responses to item number 16. Surprisingly, teachers gave less importance to "Identify the absence of knowledge" with a mean of (4.04). However, according to the literature, teachers first should help students recognize the knowledge that they already have about the topic of a text and recognize the knowledge they are lacking in order to help students build bridges between existing knowledge and new knowledge (Abraham 2002, Carrell and Floyd 1987). Therefore, it was expected that item number 16 would obtain a very high mean score from teachers' responses not the lowest.

However, in order to investigate more about teachers' views, the questionnaire also focused on the instructional practices that Omani EFL teachers usually use to activate students' prior knowledge. Therefore, Table (5) shows how teachers understand the role of prior knowledge and make instructional decisions based upon this understanding.

Table 5. Means and Standard deviation of Teachers' view of their Instructional Practices

\begin{tabular}{|c|c|c|c|}
\hline $\mathrm{N}$ & $\begin{array}{l}\text { How frequently do you use the following strategies to activate students' } \\
\text { prior knowledge in text comprehension? }\end{array}$ & Mean & $\mathrm{SD}$ \\
\hline 21 & Brainstorming the text topic & 4.32 & .86 \\
\hline 22 & Class discussion about text topic & 4.46 & .72 \\
\hline 23 & Organize the ideas on the board under headings to create relationships & 3.70 & .93 \\
\hline 24 & $\begin{array}{l}\text { Call students' attention to specific signal words, main idea, sentences, } \\
\text { highlighted phrases, headings and subtitles }\end{array}$ & 4.34 & .72 \\
\hline 25 & $\begin{array}{l}\text { List some statements on the board that are related to the reading topic to } \\
\text { guide students' reading }\end{array}$ & 3.68 & .95 \\
\hline 26 & Use visual-based questions & 3.96 & 1.05 \\
\hline 27 & Use supporting materials to display prior knowledge & 3.91 & .80 \\
\hline 28 & Develop inquiries about the text to create a purpose of reading & 4.00 & .87 \\
\hline 29 & Select key words from the text that require the students to infer text topic & 4.17 & .97 \\
\hline 30 & Link the topic to students' culture and previous experience & 4.17 & .95 \\
\hline
\end{tabular}

Regarding the instructional strategies, the results in Table (5) show that the mean scores ranged from (3.68) to (4.46) which also counted as high means. Items number 22 "Class discussion about text topic" and number 24 "Call students" attention to specific signal words, main idea, sentences, highlighted phrases, headings and subtitles" obtained the highest mean scores (4.46) \& (4.34) respectively. Then came item number 21 "Brainstorming the text topic" with a mean score of (4.32). The lowest mean scores were obtained by items number 25 "List some statements on the board that are related to the reading topic to guide students' reading" with a mean score of (3.68) and number 23 "Organize the ideas on the board under headings to create relationships" with a mean score of (3.70).

Based on teachers' responses, it seems that they are familiar with the strategies and use them regularly to activate students' prior knowledge. These results are consistent with what has been found by many studies about the role of prereading strategies (Walraven and Reitsma, 1993; Carrell, 1983; Spires and Donley, 1998 \& Rowe and Rayford, 1987).

However, we must keep in mind that teachers may claim that they use the proposed strategies and they are fully aware of the importance of these strategies. Cornford (2002) mentioned that teachers always claim that they use different reading strategies, but in reality, little explicit teaching and fostering of these specific strategies occur. Therefore, classroom observations are more effective to find out which instructional strategies teachers actually use. In other words, classroom observation will help to close the gap between what teachers know or claim they know and what they are able to do in their classrooms. 


\subsection{Teachers' Instructional Strategies for Activating Students' prior knowledge (Observation Results)}

The observation checklist was designed to identify the instructional techniques that a sample of teachers in Batinah North region employ to activate students' prior knowledge. It was meant to answer directly the second question of the present study: What are the instructional strategies that teachers use to foster the activation of prior knowledge in teaching reading in the Omani EFL classrooms?

Table 6. Number of usage and Percentages of Teachers' Instructional Strategies for Activating Students' prior knowledge

Strategies that have been observed with ( 30 ) Teachers

\begin{tabular}{|c|c|c|c|}
\hline $\mathrm{N}$ & $\begin{array}{l}\text { Prior knowledge } \quad \text { (schemata) } \\
\text { activation strategies }\end{array}$ & Number of usage & Percentage $(\%)$ \\
\hline 1 & Brainstorming & 30 & $100 \%$ \\
\hline 2 & Class discussion about text topic & 8 & $26 \%$ \\
\hline 3 & Semantic mapping & 3 & $10 \%$ \\
\hline 4 & Advance organizer & 0 & $0 \%$ \\
\hline 5 & Anticipation guide & 2 & $6 \%$ \\
\hline 6 & Use of Audiovisual aids & 14 & $46 \%$ \\
\hline 7 & Questioning & 13 & $43 \%$ \\
\hline 8 & Prediction & 3 & $10 \%$ \\
\hline 9 & Link the topic to students' culture & 2 & $6 \%$ \\
\hline 10 & $\begin{array}{l}\text { Know- Want to know- Learned (KWL } \\
\text { chart) }\end{array}$ & 0 & $0 \%$ \\
\hline
\end{tabular}

Table (6) illustrates the number of times that prior knowledge activation strategies were used by thirty teachers in thirty different reading lessons. It is apparent from this table that the most frequently used strategy is "brainstorming" which was used by all the teachers, followed by the "Use of audiovisual aids" with $(46 \%)$. "Questioning" came next with $(43 \%)$. On the other hand, two strategies were not used at all by the thirty observed teachers; "advance organizer" and "KWL" $(0 \%)$. The use of the remaining strategies ranged from $(6 \%)$ to $(26 \%)$.

From these results, it becomes clear that teachers use some of the prior knowledge activation strategies. This finding reflects to some extent teachers' awareness of the importance of pre-reading strategies in reading comprehension. The thirty teachers that were observed did not move to reading texts before using one of the pre-reading strategies, and few of them used more than one strategy to activate students' prior knowledge.

However, it is obvious that teachers rely heavily on using "brainstorming" and to some extent on "questioning" strategies. Brainstorming is just one of the strategies and teachers should deploy other techniques that can help them to activate their students' prior knowledge. Also, the researcher's notes indicate that many observed teachers did not use brainstorming efficiently. They did not spend more than two minutes to elicit specific information about the topic by asking questions or using the title to introduce the reading text. This means that teachers view "brainstorming" as an introduction to the reading text and they have to do it in order to get students to read. Therefore, most teachers use the title only to remind students about similar topics they already went through and then guide them to the new reading text. Only one teacher in Grade seven devoted a reasonable period of time for the brainstorming stage by involving students in an interesting discussion about healthy and unhealthy foods. Then, she discussed their choice between healthy or unhealthy food and encouraged them to justify their choice. It was a very successful pre-reading strategy because the teacher was able to revise the names of foods, likes and dislikes, and the names of some diseases in order to prepare students for reading the text entitled "You are what you eat".

Teachers' excessive reliance on brainstorming and questioning strategies raises many questions: Do they rely heavily on "brainstorming" and "questioning" because they lack the knowledge about other strategies? Or are there any other reasons that force them to rely more on brainstorming and ignore other available strategies?

The possible explanation for teachers' heavy reliance on few strategies is that teachers may have limited training and knowledge about the instructional implications of prior knowledge in reading lessons. This makes teachers limit their instructional practices to only one or two simple pre-reading strategies such as brainstorming and questioning. Lack of 
training became obvious in the inability of teachers to use more complex strategies such as "advance organizer" and "KWL" which were not used by any of the observed teachers.

Another possible explanation for teachers' heavy reliance on brainstorming and questioning is that these strategies do not need much preparation and can be done easily before any lesson. It seems that EFL teachers' attention is usually focused on the content they needed to teach and the information to be delivered but not on understanding students' prior knowledge and helping them activate it. The researcher's notes from the observed lessons also indicate that teachers struggle to use the appropriate strategy to activate their students' prior knowledge.

\section{The relationship between teachers' perspectives and their classroom practices}

Comparing the results of Table (6) with the results in Table (5) we can identify the discrepancy between teachers' perspectives and their classroom practices.

In fact, the inconsistency between teachers' perspectives and their classroom practices is not unexpected. Several research studies including Cornford, 2002; Basturkmen, Loewen, \& Ellis, 2004 (as cited in Fang 1996) have indicated that teachers may claim that they use different reading strategies in teaching reading, but in reality, little explicit teaching and fostering of these specific strategies occur. For instance, Fang (1996) indicated that a study by Basturkmen, Loewen, \& Ellis (2004) found evidence of incongruence between L2 teachers' stated beliefs and their classroom practices related to form-focused instruction.

A possible explanation for the inconsistency between Omani EFL teachers' perspectives and their actual classroom practices is that the teachers may lack the systematic approach of schema theory application. Although Omani EFL teachers have strong recognition of the role of prior knowledge in reading comprehension, the lack of procedural knowledge has led them to teach differently. Fang (1996) mentioned another possible explanation for the inconsistency between teachers' perspectives and their actual classroom practices. He attributed this inconsistency to other contextual factors, such as too little weekly time, big classes, students' motivation and their language competence, teachers' workload, and teachers' motivation. In fact, some of these factors correspond with Omani EFL teachers' comments about their difficulties in activating students' prior knowledge which will be discussed in next section.

\subsection{Teachers' Difficulties in Activating Students' Prior Knowledge}

The questionnaire was also designed to answer the third question of the present study: what are the difficulties that Omani EFL teachers face when activating prior knowledge in the classrooms? Only three items were listed as examples and a space was provided for teachers to mention any other difficulties. Unfortunately, only a few teachers responded to this open-ended question.

Table 7. Means and Standard deviation of Teachers' difficulties

\begin{tabular}{llll}
\hline $\mathrm{N}$ & $\begin{array}{l}\text { Are there any factors/difficulties that prevent you from activating } \\
\text { students' prior knowledge? For example: }\end{array}$ & Mean & SD \\
\hline 31 & Lack of awareness of the role of prior knowledge & 3.58 & 1.15 \\
32 & Lack of knowledge about its instructional implications & 3.52 & .83 \\
33 & Lack of training on a variety of techniques & 3.63 & 1.01 \\
\hline
\end{tabular}

It is apparent from Table (7) that the mean scores of the three items were very close and ranged from (3.52) to (3.63). The highest mean score was obtained by item number 33 "Lack of training on a variety of techniques" with a mean score of (3.63).

Surprisingly, a majority of teachers indicated that they are suffering from "Lack of knowledge about the role of prior knowledge" with a mean score of (3.58) as well as "Lack of knowledge about its instructional implications" with a mean score of (3.52). This sounds contradictory if we bear in mind that respondents had already given strong agreements for the role of prior knowledge in reading comprehension as seen in Table (2). Also, the results contradict teachers' responses in Table (5) that they are familiar with the activation strategies and use them regularly to activate students' prior knowledge.

Moreover, teachers were asked in the open-ended questions in this part to specify any other difficulties that prevent them from activating students' prior knowledge. One unanticipated finding from teachers' responses was the attribution of their difficulty in activating prior knowledge to students' low level in reading. They think that students' low ability in reading does not help them to use activation strategies. Teachers mentioned also that students lack the knowledge, and that the time allotted for reading is not sufficient. They also claim that reading texts are not suitable for students' level and are not interesting for them. It seems that some of these difficulties are not related only to content schema, but also related to formal schema. The following table lists the specified difficulties. 
1 Students' low level in reading

$40 \%$

2 Students lack the knowledge

$10 \%$

3 Lack of resources that can help the teachers and students (books, magazines, etc)

4 Types of reading texts are above students' level

$20 \%$

$10 \%$

5 Different cultures of students and teacher

$10 \%$

$\begin{array}{ll}\text { Students do not prepare for reading texts at home } & 30 \% \\ \text { Time allotted for reading texts is not enough } & 10 \%\end{array}$

7 Time allotted for reading texts is not enough

8 Reading texts are not interesting for students

We can conclude that Omani EFL teachers who took part in the present study may be aware of the importance of the role of prior knowledge in reading comprehension, but they have limited awareness of its instructional implications. It seems that they relied on their students' prior knowledge being there and on their reading competence. Therefore, the low level of the students has a negative impact on teachers' ability to activate students' prior knowledge. One possible explanation for this is that teachers lack training on a variety of techniques for activating students' prior knowledge. It also appears that Omani EFL teachers did not get enough training opportunities to develop an adequate understanding of prior knowledge and its implications. Teachers need to have a more complex view of prior knowledge and of how they can use their students' prior knowledge effectively. Another possible explanation is that Teacher's Book does not provide teachers with enough information or strategies to help them in dealing with students' prior knowledge in order to enhance text comprehension. The Teacher's Book should also take into account the different abilities of teachers and that there are new teachers who have a limited experience. For example, the KWL chart which is a well known strategy needs to be included not just in the Teacher's Book, but also in the Textbooks.

The semi-structured interviews revolved around the three main questions of the study to find out more information about teachers' perceptions, strategies, and any difficulties in activating students' prior knowledge. After analyzing teachers' answers to the three questions, we got more evidence in support of the above mentioned findings.

First, 15 teachers were asked if they usually activate students' prior knowledge before reading lessons. The teachers' answer was "Yes", but few of them were able to give reasonable justifications for that. The majority of the teachers mentioned that prior knowledge activation can prepare students for reading. This finding explains why EFL teachers rely heavily on few strategies. However, few of them show good understanding of the role of prior knowledge and its effect on reading comprehension. For instance, one teacher said:

“Yes, I activate students' prior knowledge before reading because it helps me to involve all students. Also it gives me an idea about how much students know about the topic".

Another teacher stated:

“Yes I activate students' prior knowledge before reading because it helps students to comprehend the text. Also, to help students to be familiar with the topic and familiar with names in the text, etc".

Second, the teachers were asked about the pre-reading strategies they use to activate students' prior knowledge. The common strategies mentioned by about $73 \%$ of those who were interviewed were "questioning" and "brainstorming". Also, about $66 \%$ of the teachers mentioned that they use "audiovisual aids" such as pictures, posters, etc to activate students' prior knowledge. A small number of teachers mentioned "guessing" and "prediction." However, none of them mentioned the following strategies "semantic mapping", "advance organizer", "anticipation guide", and "KWL", which are more complex and more structured instructional strategies. This supports findings obtained through classroom observations regarding the use of particular strategies and teachers' limited knowledge about the more complex ones.

Third, the interviewees were asked if there were any difficulties that prevented them from activating students' prior knowledge. The majority of the respondents emphasized three main difficulties. First, they insisted that students' limited linguistic competence does not allow them to express their ideas about what they know. Also, the time allotted for reading is very limited which puts the teacher under considerable pressure to complete the lesson. In addition, they mentioned that the Teacher's Book is not very helpful because the suggested techniques are not always applicable and also it does not provide additional information about prior knowledge activation.

\section{Summary and Conclusion}

The study investigated three main aspects related to prior knowledge in EFL reading comprehension in Oman: teachers' view of the role of prior knowledge, the instructional strategies they use for activating students' prior knowledge, and the difficulties they face when activating students' prior knowledge.

To this end, three instruments were used: a questionnaire, an observation checklist, and a semi-structured interview. Analysis of teachers' responses and classroom practices shows the following main findings:

1. A strong agreement of the role of prior knowledge in text comprehension. 
2. A heavy reliance on a limited number of techniques (brainstorming, audiovisual aids, and questioning) and the absence of use of well-structured techniques such as advance organizer and KWL.

3. A clear attribution of the difficulties to three main sources: first, students have limited linguistic competence which does not enable them to express the wealth of knowledge they possess or use it for constructing meaning. Second, teachers lack adequate training on schema theory and its instructional implications and techniques. Finally, Teachers' Books provide little help on how to deal with prior knowledge activation through a variety of techniques.

Among the other results from the analysis of teachers' responses and classroom practices:

1. EFL teachers agreed that sufficient prior knowledge about text topic can influence students' recall and comprehension.

2. EFL Teachers believe that a "good reader" is one who can employ his prior knowledge to comprehend the text by using any available sources, such as text's title and illustrations.

3. EFL teachers expressed strong agreement on the teacher's role in fostering text comprehension with the use of students' prior knowledge mainly by asking questions before, during and after reading, and providing students with appropriate prior knowledge if they lack it.

4. Regarding the instructional practices, teachers' responses show that they focus more on the following strategies; "class discussion about text topic", "calling students' attention to specific signal words, main idea, sentences, highlighted phrases, headings and subtitles", and "brainstorming about the text topic".

5. Observation results show that the most frequently used strategies are "brainstorming", "using audiovisual aids", and "questioning". On the other hand, no teachers used strategies that tend to be more complex and structured such as "advance organizer" and "KWL".

6. EFL teachers also indicated that the time allotted for reading is not sufficient for activating students' prior knowledge.

The current study shows some evidence that support teachers' awareness of the important role of prior knowledge in reading comprehension and their claim of the familiarity with the appropriate instructional strategies and the use of these strategies regularly to activate students' prior knowledge. These findings are supported by previous studies such as Langer and Nicolich, 1980; Carrell, 1983; Rowe and Rayford, 1987; Walraven and Reitsma, 1993; and Spires and Donley, 1998). However, the findings showed inconsistency between teachers' perspectives and their classroom practices which is in consistent with Cornford, 2002; Loewen and Ellis, 2004 (as cited by Fang 1996).

\section{Implications and Recommendations}

The results of the current study have implications for classroom teachers, supervisors and administrators and curriculum developers. Teachers need to pay more attention to help students make connections between their prior knowledge and new reading materials through appropriate pre-reading activities. Teachers should also be aware that even though it might take them more time to prepare pre-reading activities and implement them, the benefits gained from these activities merit the effort as the activities contribute to improving learners' reading comprehension.

Teachers' limited awareness of prior knowledge and its implementation demands immediate action from supervisors and administrators. Teachers need to be coached on how to implement several teaching practices. Therefore, more professional development through in-service teacher training is needed to aid teachers in the successful practice and implementation of a variety of background knowledge activation strategies. Teachers need to be provided with formal and informal training that guide them in the systematic utilization of reading strategies aimed at enhancing the reading comprehension. In this regard, the Teacher's Book can play an essential role in providing many examples of effective reading comprehension instructional techniques.

As for the recommendations, further research studies into related issues can be recommended. Indeed, future research investigations should:

1. Include a larger sample from more regions and different grade levels in order to be able to understand Omani EFL teachers' views and their instructional practices regarding prior knowledge.

2. Extend investigation to identify other groups' views of prior knowledge, such as supervisors and curriculum designers, to know how closely they match teachers' views.

3. Investigate other factors that may influence teachers' views and their instructional practices (gender, qualification, and years of experience).

4. Examine the effects of a schema-based teacher development program on their classroom practices,

5. Explore the differential effects of various techniques on students' comprehension or the effects of knowledge absence and availability on students' step-by-step processing of text information.

6. Conduct an observation study with a much larger sample in order to make a more confident portrait of the classroom practices.

7. Conduct an experimental study to identify the best strategies for activating students' prior knowledge in Omani EFL classrooms. 


\section{References}

Abraham, P. (2002). Skilled Reading: Top-down, bottom-up. Field Notes, 10 (2). SABES/World Education, Boston, MA.

Al Ajmi, S. (2006). Omani EFL students' perceptions of reading difficulties. Unpublished MA dissertation, Sultan Qaboos University, Oman.

Al Brashdi, B. (2002). Reading in English as a foreign language: problems and strategies. Unpublished MA dissertation, Sultan Qaboos University, Oman.

Alderson, J. C. (2000). Assessing Reading. Cambridge: Cambridge University Press.

Al-Issa, A. (2006). Schema theory and reading comprehension: implications for teaching. Journal of College Teaching \& Learning, 3(7).

Anderson, R. C. (1994). Role of the reader's schema in comprehension, learning, and memory. Newark, Delaware: International Reading Association.

Bernhardt, E.B. (1991). Reading development in a second language: Theoretical, empirical and classroom perspectives. Norwood, NJ: Ablex Publishing Corporation.

Brantmeier, C. (2004). Gender, violent-oriented passage content and second language reading comprehension. The Reading Matrix, 4(2), 1-19.

Carrell, P. (1983). Some issues in studying the role of schemata, or background knowledge, in second language comprehension. Reading in a Foreign Language, 1(2), 81-92.

Carrell, P. \& Eisterhold, J. (1983). Schema theory and ESL reading. TESOL Quarterly, 17, 553-573.

Carrell, P. \& Floyd, P. (1987). Effects on ESL reading of teaching cultural content schema. Language Learning, TESOL Quarterly, 37, 88-108.

Chen, C. (2003). Mainstream teachers' practices and accommodations in prereading instructions for English language learners. Unpublished Doctoral Dissertation, University of Utah.

Cornford, I. R. (2002). Learning-to-learn strategies as a basic foe effective lifelong learning. International Journal of lifelong Education, 21(4), 357-368.

Dayze, F. (2004). The role of prior background knowledge in the reading comprehension of EFL Brazilian college students and American college students. Unpublished PhD dissertation The Pennsylvania State University.

Fang, Z. (1996). A review of research on teacher beliefs and practices. Educational Research, 38(1), 47-65.

Grabbe, W. (1991). Current developments in second language reading research. TESOL Quarterly 25(3), 375-406.

Johnson, P. (1981). Effects on reading comprehension of language complexity and cultural background of a text. TESOL Quarterly, 15 (2), 169-181.

Langer, A. \& Nicolich, M. (1980). Effect of Altered Prior Knowledge on Passage Recall. Eric. ED 197282

Lin, L. (2004). Effects of culturally specific prior knowledge on Taiwanese EFL students' English reading comprehension. University of Victoria.

Murray. (1980). The effect of two techniques which elicit productive response on the comprehension of content area reading materials. Unpublished MA dissertation. The University of Connecticut.

Ringler, L. h. \& Weber, C.K. (1984). A language -Thinking Approach to Reading. San Diego: Harcourt Brace Jovanovich, Ink.

Rowe, D.W, \& Rayford, L. (1987). Activating background knowledge in reading comprehension assessment. Reading Research Quarterly, 22(2), 160-176.

Spires, H.A. \& Donley, J. (1998). Prior knowledge activation: Inducing engagement with informational texts. Journal of Educational Psychology, 90, 1-12.

UR, P. (1996). A Course in Language Teaching. Cambridge: Cambridge University Press.

Walraven, M. \& Reitsma, P. (1993). The effect of teaching strategies for reading comprehension to poor readers and the possible surplus effect of activating prior knowledge. National Reading Conference Yearbook, 42, 243-250. 


\section{Appendix A}

Questionnaire of Teachers' view of the role of prior knowledge in EFL reading comprehension Please answer this Questionnaire honestly. Please $(\sqrt{ })$ what you think is the most appropriate response to each statement.

\begin{tabular}{|c|c|c|c|c|c|c|}
\hline \multicolumn{2}{|c|}{ Statements } & \multirow[t]{2}{*}{$\begin{array}{l}\text { Strongly } \\
\text { agree }\end{array}$} & \multirow[t]{2}{*}{ Agree } & \multirow{2}{*}{$\begin{array}{l}\text { Agree } \\
\text { to some } \\
\text { extent } \\
\end{array}$} & \multirow[t]{2}{*}{ Disagree } & \multirow[t]{2}{*}{$\begin{array}{l}\text { Strongly } \\
\text { disagree }\end{array}$} \\
\hline $\mathbf{N}$ & Part One: Teachers' Views & & & & & \\
\hline & A. Views of the role of the prior knowledge: & & & & & \\
\hline \multicolumn{2}{|r|}{$\begin{array}{l}\text { When students have sufficient prior knowledge about text } \\
\text { topic, they can: }\end{array}$} & & & & & \\
\hline 1 & Understand text better & & & & & \\
\hline 2 & Recall information easily & & & & & \\
\hline 3 & Read text quickly & & & & & \\
\hline 4 & Link the ideas in the text easily & & & & & \\
\hline 5 & Focus on main ideas & & & & & \\
\hline 6 & Overcome limited linguistic knowledge & & & & & \\
\hline 7 & Relate text to their own prior knowledge & & & & & \\
\hline 8 & Predict text content easily & & & & & \\
\hline \multirow[t]{3}{*}{9} & Confirm predictions based on prior knowledge & & & & & \\
\hline & \multicolumn{6}{|l|}{ Other (specify) } \\
\hline & B. Views of good readers: & & & & & \\
\hline \multicolumn{2}{|c|}{ The Good readers: } & & & & & \\
\hline $\begin{array}{l}1 \\
\mathbf{0}\end{array}$ & $\begin{array}{l}\text { Use their personal knowledge of the topic of the text to } \\
\text { make sense of the text }\end{array}$ & & & & & \\
\hline $\begin{array}{l}1 \\
1\end{array}$ & $\begin{array}{l}\text { Are able to activate their prior knowledge to create } \\
\text { meaning of the text }\end{array}$ & & & & & \\
\hline $\begin{array}{l}1 \\
2\end{array}$ & $\begin{array}{l}\text { Use text's title, illustrations and other clues to predict } \\
\text { the content. }\end{array}$ & & & & & \\
\hline $\begin{array}{l}1 \\
3\end{array}$ & $\begin{array}{l}\text { Use the directions provided by the text to construct } \\
\text { meaning }\end{array}$ & & & & & \\
\hline & \multicolumn{6}{|l|}{ Other (specify) } \\
\hline
\end{tabular}

\begin{tabular}{|c|c|c|c|c|c|c|}
\hline \multicolumn{2}{|c|}{ Statements } & $\begin{array}{l}\text { Strongly } \\
\text { agree }\end{array}$ & Agree & $\begin{array}{l}\text { Agree to } \\
\text { some } \\
\text { extent }\end{array}$ & Disagree & $\begin{array}{l}\text { Strongly } \\
\text { disagree }\end{array}$ \\
\hline $\mathbf{N}$ & C. Views of the role of the teacher: & & & & & \\
\hline \multicolumn{7}{|c|}{$\begin{array}{l}\text { To foster text comprehension with the use of students' prior } \\
\text { knowledge, it is important for teachers to: }\end{array}$} \\
\hline 14 & $\begin{array}{l}\text { Provide students with appropriate prior } \\
\text { knowledge }\end{array}$ & & & & & \\
\hline 15 & Activate available prior knowledge & & & & & \\
\hline
\end{tabular}




\begin{tabular}{|c|c|c|c|c|c|c|}
\hline 16 & Identify the absence of knowledge & & & & & \\
\hline 17 & $\begin{array}{l}\text { Raise students' awareness of the role of prior } \\
\text { knowledge }\end{array}$ & & & & & \\
\hline 18 & Ask questions before, during and after reading & & & & & \\
\hline 19 & $\begin{array}{l}\text { Encourage students to summarize what they have } \\
\text { read }\end{array}$ & & & & & \\
\hline 20 & $\begin{array}{l}\text { Elicit background information related to the } \\
\text { reading topic }\end{array}$ & & & & & \\
\hline & Other (specify) & & & & & \\
\hline \multicolumn{2}{|c|}{ Part Two: The Instructional Practices: } & \multirow{2}{*}{ 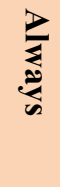 } & \multirow{2}{*}{ 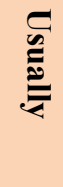 } & \multirow{2}{*}{ 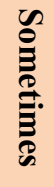 } & \multirow{2}{*}{ 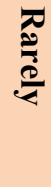 } & \multirow{2}{*}{ Z } \\
\hline \multicolumn{2}{|c|}{$\begin{array}{l}\text { How frequently do you use the following strategies to activate } \\
\text { students'prior knowledge in text comprehension? }\end{array}$} & & & & & \\
\hline 21 & Brainstorming the text topic & & & & & \\
\hline 22 & Class discussion about text topic & & & & & \\
\hline 23 & $\begin{array}{l}\text { Organize the ideas on the board under headings } \\
\text { to create relationships }\end{array}$ & & & & & \\
\hline 24 & $\begin{array}{l}\text { Call students' attention to specific signal words, } \\
\text { main idea, sentences, highlighted phrases, } \\
\text { headings and subtitles }\end{array}$ & & & & & \\
\hline 25 & $\begin{array}{l}\text { List some statements on the board that are related } \\
\text { to } \\
\text { the reading topic to guide students' reading }\end{array}$ & & & & & \\
\hline 26 & Use visual-based questions & & & & & \\
\hline 27 & $\begin{array}{l}\text { Use supporting materials to display prior } \\
\text { knowledge }\end{array}$ & & & & & \\
\hline 28 & $\begin{array}{l}\text { Develop inquiries about the text to create a } \\
\text { purpose of reading }\end{array}$ & & & & & \\
\hline 29 & $\begin{array}{l}\text { Select key words from the text that require the } \\
\text { students to infer text topic }\end{array}$ & & & & & \\
\hline 30 & $\begin{array}{l}\text { Link the topic to students' culture and previous } \\
\text { experience }\end{array}$ & & & & & \\
\hline & Other (specify) & & & & & \\
\hline
\end{tabular}

\section{Part Three: Difficulties Related to Prior Knowledge Activation:}

\begin{tabular}{|l|l|l|l|l|l|}
\hline \multicolumn{2}{|l|}{$\begin{array}{l}\text { Are there any factors/difficulties that prevent you from } \\
\text { activating students'prior knowledge? For example: }\end{array}$} & $\begin{array}{l}\text { Strongly } \\
\text { agree }\end{array}$ & Agree & $\begin{array}{l}\text { Agree to } \\
\text { some } \\
\text { extent }\end{array}$ & Disagree \\
\hline 31 & $\begin{array}{l}\text { Lack of knowledge about the role of prior } \\
\text { disagree }\end{array}$ & & & \\
\hline 32 & $\begin{array}{l}\text { Lack of knowledge about its instructional } \\
\text { implications }\end{array}$ & & & & \\
\hline 33 & Lack of training on a variety of techniques & & & \\
\hline
\end{tabular}

\section{Other difficulties (specifv):}


Observational Checklist

Appendix B

(The Role of Prior knowledge in EFL Reading Comprehension)

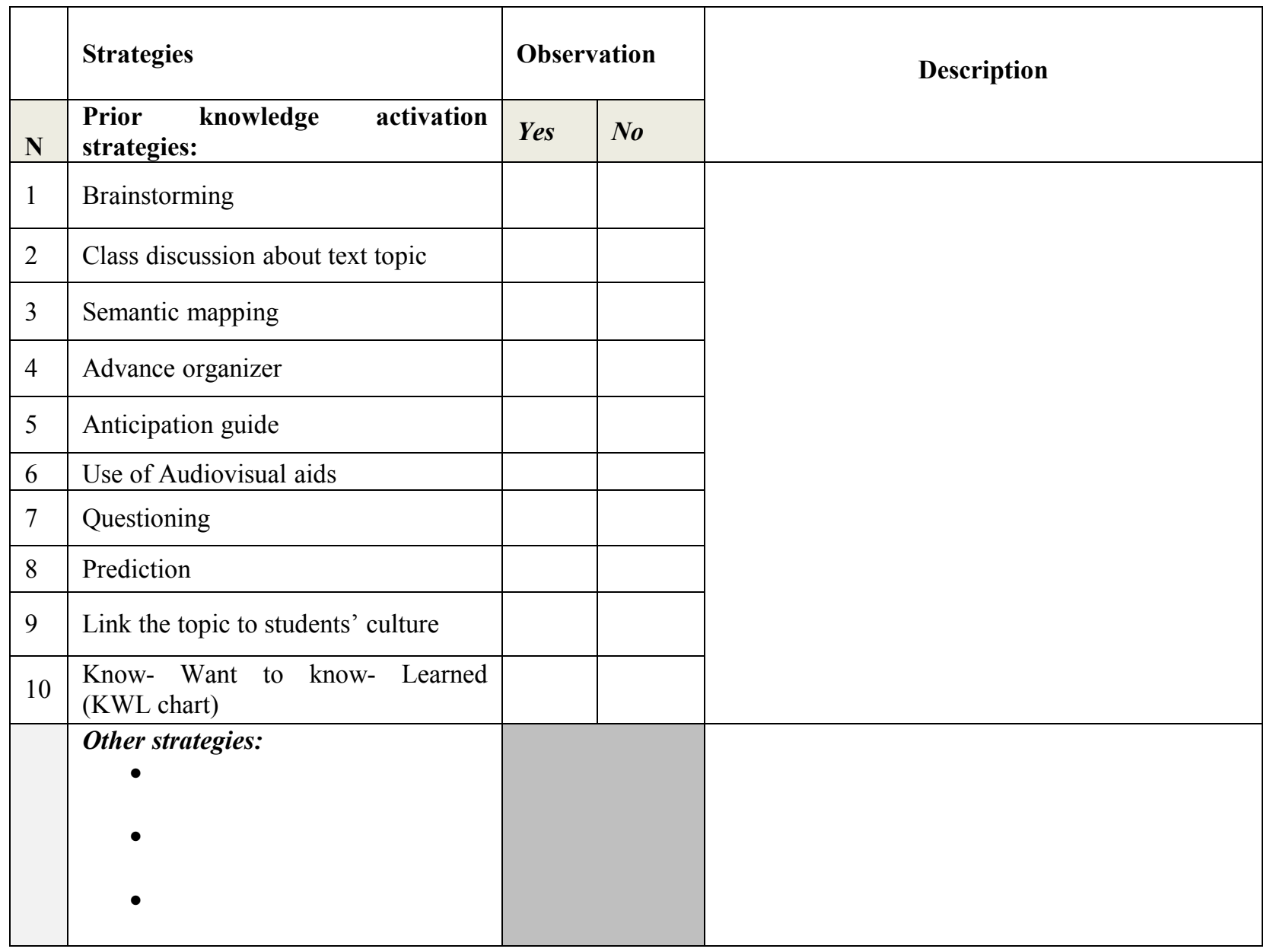

